\title{
A Method for Estimating Caribou Consumption by Northern Canadians
}

\author{
B.L. TRACY ${ }^{1,2}$ and G.H. KRAMER ${ }^{1}$
}

(Received 14 July 1998; accepted in revised form 30 September 1999)

\begin{abstract}
Caribou is an important source of protein in the diet of northern Canadians. It is also an important pathway for airborne environmental contaminants that concentrate in the lichen $\rightarrow$ caribou $\rightarrow$ human food chain. We present a method for estimating caribou consumption that is independent of questionnaires and dietary surveys. The method is based on direct, wholebody measurements of fallout radiocesium in northern caribou consumers and on measurements of the concentrations of radiocesium in the meat. From the 1989-90 surveys of five Arctic communities, we obtained the following mean (90th percentile) intakes of caribou meat in grams per day: Baker Lake - males 65 (141), females 41 (88); Rae-Edzo - males 42 (103), females 31 (80); Old Crow - males 41 (108), females 23 (59); Fort McPherson - males 41 (77), females 32 (68); Aklavik - males 20 (47), females 15 (37). Compared with surveys carried out in the late 1960s, these values indicate a twofold to fourfold decrease in caribou consumption over a period of 20 years. A dietary survey questionnaire administered during the 1989-90 survey provided useful information on the consumption of various caribou organs, methods of meat preparation, and consumption of other traditional foods.
\end{abstract}

Key words: aboriginal foods, caribou, cesium-137, radiocesium, traditional foods

RÉSUMÉ. Le caribou constitue une importante source de protéines dans le régime alimentaire des Canadiens. Il représente également une voie d'entrée majeure pour les contaminants environnementaux en suspension dans l'air, qui se concentrent dans la chaîne alimentaire lichen $\rightarrow$ caribou $\rightarrow$ être humain. Nous présentons une méthode d'évaluation de la consommation de caribou qui n'est pas fondée sur des questionnaires et sondages alimentaires. La méthode s'appuie sur des mesures directes du césium radioactif provenant de retombées, mesures effectuées sur le corps entier de consommateurs nordiques de caribou, ainsi que sur des mesures de la concentration de césium radioactif dans la viande. À partir des enquêtes menées en 1989 et 1990 dans cinq communautés de l'Arctique, nous avons obtenu les apports moyens suivants (90 percentile) de viande de caribou en grammes par jour: Baker Lake - hommes 65 (141), femmes 41 (88); Rae-Edzo - hommes 42 (103), femmes 31 (80); Old Crow - hommes 41 (108), femmes 23 (59); Fort McPherson - hommes 41 (77), femmes 32 (68); Aklavik - hommes 20 (47), femmes 15 (37). Quand on les compare aux sondages menés à la fin des années 1960, ces valeurs révèlent une baisse de 50 à 75 p. cent dans la consommation de caribou sur une période de 20 ans. Une enquête alimentaire réalisée de 1989 à 1990 à l'aide d'un questionnaire a fourni des renseignements utiles sur la consommation de divers abats, les méthodes d'apprêt de la viande ainsi que la consommation d'autres aliments traditionnels.

Mots clés: aliments autochtones, caribou, césium 137, césium radioactif, aliments traditionnels

Traduit pour la revue Arctic par Nésida Loyer.

\section{INTRODUCTION}

Although aboriginal peoples constitute less than $3 \%$ of the Canadian population as a whole, they comprise about $50 \%$ of a population of 93000 in the Arctic region of Canada, which includes Yukon, the Northwest Territories, Nunavut, northern Quebec, and Labrador (Statistics Canada, 1995). These peoples belong to three major groups - the Inuit, the Dene (a grouping of North American Indian tribes), and the Métis (of partial aboriginal origin). Most of these people live in communities of 1000 or less and rely to a large extent on traditional hunting and food-gathering activities.
The study of the dietary intake of traditional or "country" foods among Canada's northern peoples is important for assessing their exposure to environmental contaminants. Arctic ecosystems are particularly vulnerable to the presence of persistent organic pollutants, trace metals, and radionuclides. Some of these contaminants originate from local activities; others are transported thousands of kilometres from industrial and agricultural sources in the south. Dietary information is also valuable for epidemiological studies on the relationship of contaminants to the incidence of disease. Furthermore, it is important for ensuring that Northerners obtain a good supply of essential nutrients. Traditional foods are also important for main-

\footnotetext{
${ }^{1}$ Radiation Protection Bureau 6302D1, Health Canada, Ottawa, Ontario K1A 1C1, Canada

2 B_L_Tracy@hc-sc.gc.ca

(C) The Arctic Institute of North America
} 
taining cultural and spiritual values among aboriginal peoples (See Indian and Northern Affairs Canada, 1997: Chapter 4).

General methods for obtaining dietary intake information (precise weighing, dietary record, 24-hour recall, food frequency survey, harvest survey) have been summarized by Marr (1971), Block (1982), and Witschi (1990). Not all of these methods are suitable for obtaining quantitative estimates of traditional food intakes. The blend of items in traditional diets may vary greatly from season to season, or even from day to day, depending on the availability of various foods. In many cases, interviews and questionnaires must be administered in aboriginal languages, whose concepts are very different from those expressed by the terminology of Western science. Furthermore, there may be certain cultural values, not apparent to Western investigators, that would lead some Northerners to overestimate or underestimate their intakes of certain food items.

The precise weighing method and the dietary record method require a high degree of literacy and motivation on the part of the subjects. They also require a significant degree of supervision and follow-up by the investigators. Such methods are best suited to small numbers of volunteers, but are not appropriate for community-wide food consumption patterns. The 24-hour recall method (Burke, 1947) has been shown to give good information on group averages. The information on individual consumption is less reliable, since a given 24-hour period may not be typical for a certain individual. This problem can be overcome to some extent by the use of multiple 24-hour recalls administered to the same person. Dietary records and food frequency surveys give useful qualitative information on patterns of food consumption but can rarely be relied upon for precise quantitative information. All methods based on recall suffer from the possibility of biases and omissions in reporting (Witschi, 1990).

Coad (1994) has compiled most of the available dietary data from the Canadian North. The available results exhibit wide variation and inconsistencies. Although 24hour recall surveys (Szathmary et al., 1987; Kuhnlein and Kinloch, 1988; Kinloch et al., 1992) and food frequency surveys (Wein and Freeman, 1995) have been carried out in a few communities, most of the intake estimates are based on harvest surveys. In this method, the numbers of animals collected from each species in hunting and fishing activities are divided by the number of persons dependent upon the harvest to obtain a per capita estimate of consumption (Usher and Wenzel, 1987). Harvest records are collected by a variety of government agencies and organizations, often for different purposes. Allowances must be made for food given away or sold, for meat given to dogs, for cooking losses, and for spoilage and waste. Harvest surveys have a tendency to overestimate consumption. Coad (1994) has shown that a harvest survey for Broughton Island gave consumptions about four times as high as those derived from a 24-hour recall survey.
In this paper we report a different method of obtaining consumption estimates of meat from the caribou (Rangifer tarandus), one of the most important protein sources in northern diets. The method uses radioactive ${ }^{137} \mathrm{Cs}$ as a tracer. The human uptake of fallout radiocesium in the North through the lichen $\rightarrow$ caribou $\rightarrow$ human food chain can be readily measured by means of a portable wholebody counter. If the concentration of ${ }^{137} \mathrm{Cs}$ in the caribou meat is also known, then one can estimate the amount of meat consumed. Whole body surveys of ${ }^{137} \mathrm{Cs}$ were carried out by Health Canada on about 3000 residents of the Canadian Arctic during the late 1960s (Bird, 1968; Tracy et al., 1997) and on 1100 residents in 1989-90 (Tracy and Kramer, 1993; Tracy et al., 1997).

This method has a number of advantages. It is rapid $(\sim 5$ minutes per measurement) and suitable for large numbers of people. It is independent of recall bias. It can confirm data gathered by surveys and questionnaires and provides information on individual intake. The consumption estimate, the important quantity for assessing chronic exposure to environmental contaminants, is averaged over a period of several months. It is possible to obtain historical information on caribou consumption from earlier body burden measurements of radiocesium.

During the 1989-90 survey, respondents were asked to complete a food frequency questionnaire. It was subsequently found that the responses did not allow reliable quantitative estimates of caribou consumption. They did, however, give useful information on consumption of organs, methods of food preparation, and other traditional foods consumed. We report these results here as a guide to other researchers studying dietary patterns among northern Canadians.

\section{MATERIALS AND METHODS}

\section{Derivation of Caribou Consumption from Body Burden Measurements}

If the human radiocesium body burden is in equilibrium with intake, then the following relationship holds (ICRP, 1979):

$$
\begin{aligned}
& \text { Body burden }(\mathrm{Bq})=\text { meat conc. }\left(\mathrm{Bq} \mathrm{g}^{-1}\right) \\
& \times \text { consumption }\left(\mathrm{g} \mathrm{d}^{-1}\right) \times \mathrm{f}_{1} \times \mathrm{T}_{1 / 2}(\mathrm{~d}) / \ln (2)
\end{aligned}
$$

where $\mathrm{f}_{1}=$ the fractional uptake of radiocesium by the GI tract and $\mathrm{T}_{1 / 2}=$ the effective half time (days) of radiocesium in the body.

Equation (1) can be rearranged to give an estimate of meat consumption:

$$
\begin{aligned}
& \text { Consumption }\left(\mathrm{g} \mathrm{d}^{-1}\right)=\text { Body burden }(\mathrm{Bq}) / \\
& \left\{\text { meat conc. }\left(\mathrm{Bq} \mathrm{g}^{-1}\right) \times \mathrm{f}_{1} \times \mathrm{T}_{1 / 2} / \ln (2)\right\}
\end{aligned}
$$


TABLE 1. Caribou consumption estimates derived from radiocesium body burden measurements.

\begin{tabular}{|c|c|c|c|c|c|c|c|c|c|}
\hline \multirow[t]{2}{*}{ Community } & \multicolumn{2}{|c|}{$\begin{array}{l}{ }^{137} \mathrm{Cs} \text { concentration } \\
\text { in meat }(\mathrm{Bq} / \mathrm{g}) \\
\end{array}$} & \multirow[t]{2}{*}{ Gender } & \multicolumn{2}{|c|}{$\begin{array}{l}\text { Number } \\
\text { of subjects }\end{array}$} & \multicolumn{2}{|c|}{$\begin{array}{l}{ }^{137} \mathrm{Cs} \text { body burden }(\mathrm{Bq}) \\
\text { average (90th percentile) }\end{array}$} & \multicolumn{2}{|c|}{$\begin{array}{l}\text { Meat consumption (grams/day) } \\
\text { average (90th percentile) }\end{array}$} \\
\hline & $1967-68$ & $1989-90$ & & $1967-68$ & $1989-90$ & $1967-68$ & $1989-90$ & $1967-68$ & $1989-90$ \\
\hline Baker Lake & 2.0 & 0.21 & $\begin{array}{l}\mathrm{M} \\
\mathrm{F}\end{array}$ & $\begin{array}{l}91 \\
99\end{array}$ & $\begin{array}{l}116 \\
139\end{array}$ & $\begin{array}{l}36700(82100) \\
30000(55400)\end{array}$ & $\begin{array}{l}1860(4050) \\
800(1700)\end{array}$ & $\begin{array}{l}132(297) \\
160(296)\end{array}$ & $\begin{array}{l}65(141) \\
41(88)\end{array}$ \\
\hline Rae-Edzo & 2.0 & 0.29 & $\begin{array}{l}\mathrm{M} \\
\mathrm{F}\end{array}$ & $\begin{array}{l}63 \\
21\end{array}$ & $\begin{array}{l}185 \\
156\end{array}$ & $\begin{array}{l}37500(56200) \\
28000(43000)\end{array}$ & $\begin{array}{l}1720(4210) \\
867(2210)\end{array}$ & $\begin{array}{l}135(203) \\
149(229)\end{array}$ & $\begin{array}{l}42(103) \\
31(80)\end{array}$ \\
\hline Old Crow & 0.75 & 0.092 & $\begin{array}{l}\mathrm{M} \\
\mathrm{F}\end{array}$ & $\begin{array}{l}30 \\
19\end{array}$ & $\begin{array}{l}40 \\
24\end{array}$ & $\begin{array}{l}17200(29400) \\
15700(21900)\end{array}$ & $\begin{array}{l}525(1380) \\
202(505)\end{array}$ & $\begin{array}{l}165(283) \\
224(311)\end{array}$ & $\begin{array}{l}41(108) \\
23(59)\end{array}$ \\
\hline Fort McPherson & 0.75 & 0.092 & $\begin{array}{l}\mathrm{M} \\
\mathrm{F}\end{array}$ & $\begin{array}{l}36 \\
25\end{array}$ & $\begin{array}{l}43 \\
64\end{array}$ & $\begin{array}{l}12500(18600) \\
7900(11600)\end{array}$ & $\begin{array}{l}521(978) \\
275(586)\end{array}$ & $\begin{array}{l}121(179) \\
112(165)\end{array}$ & $\begin{array}{l}41(77) \\
32(68)\end{array}$ \\
\hline Aklavik & 0.75 & 0.092 & $\begin{array}{c}\mathrm{M} \\
\mathrm{F}\end{array}$ & $\begin{array}{r}35 \\
5\end{array}$ & $\begin{array}{l}38 \\
58\end{array}$ & $\begin{array}{l}6900(13200) \\
4460(5660)\end{array}$ & $\begin{array}{l}251(598) \\
131(322)\end{array}$ & $\begin{array}{l}66(127) \\
63(80)\end{array}$ & $\begin{array}{l}20(47) \\
15(37)\end{array}$ \\
\hline Reindeer Station & 0.53 & - & $\begin{array}{l}\mathrm{M} \\
\mathrm{F}\end{array}$ & $\begin{array}{l}29 \\
26\end{array}$ & - & $\begin{array}{l}9840(16400) \\
6000(8840)\end{array}$ & - & $\begin{array}{l}135(226) \\
122(180)\end{array}$ & - \\
\hline Rae Lakes & 2.0 & - & $\begin{array}{l}\mathrm{M} \\
\mathrm{F}\end{array}$ & $\begin{array}{r}20 \\
8\end{array}$ & & $\begin{array}{l}58700(79000) \\
57400(70100)\end{array}$ & - & $\begin{array}{l}212(285) \\
306(374)\end{array}$ & - \\
\hline $\begin{array}{l}\text { Forts Good Hope, } \\
\text { Norman \& Franklin }\end{array}$ & 0.75 & - & $\begin{array}{l}\mathrm{M} \\
\mathrm{F}\end{array}$ & $\begin{array}{r}101 \\
13\end{array}$ & - & $\begin{array}{l}12200(20900) \\
7390(11400)\end{array}$ & - & $\begin{array}{l}118(201) \\
105(161)\end{array}$ & - \\
\hline Colville Lake & 0.75 & - & $\begin{array}{l}\mathrm{M} \\
\mathrm{F}\end{array}$ & $\begin{array}{l}41 \\
25\end{array}$ & - & $\begin{array}{l}50200(72500) \\
44900(59500)\end{array}$ & - & $\begin{array}{l}483(698) \\
638(846)\end{array}$ & - \\
\hline Snowdrift & 2.0 & - & $\begin{array}{l}\mathrm{M} \\
\mathrm{F}\end{array}$ & $\begin{array}{l}18 \\
13\end{array}$ & - & $\begin{array}{l}51300(73000) \\
32100(57600)\end{array}$ & - & $\begin{array}{l}185(264) \\
171(307)\end{array}$ & - \\
\hline Lac La Martre & 2.0 & - & $\begin{array}{l}\mathrm{M} \\
\mathrm{F}\end{array}$ & $\begin{array}{r}20 \\
9\end{array}$ & - & $\begin{array}{l}28500(33400) \\
22900(31300)\end{array}$ & - & $\begin{array}{l}103(121) \\
122(167)\end{array}$ & - \\
\hline
\end{tabular}

\section{Body Burden Measurements}

The most important term in Equation (2) is the measured body burden of radiocesium. The measurements described here were carried out in two surveys, one during 1967-68 and the other during 1989-90. The methodology of both surveys has been described previously (Overton and Lecuyer, 1967; Bird, 1968; Tracy et al., 1997). In the earlier survey, a $7.5 \mathrm{~cm} \times 7.5 \mathrm{~cm} \mathrm{NaI}(\mathrm{Tl})$ scintillation detector was placed between the thighs and near the crotch of a seated subject, who was bent over the detector and almost completely surrounded it. During a five-minute counting time, the ${ }^{137} \mathrm{Cs}$ content of the body burden was determined from the photopeak at $661.6 \mathrm{keV}$. Calibration was carried out by comparison with ${ }^{40} \mathrm{~K}$, for which the human body content is well known for a person of a given height and weight. The calibration was checked against a similar American system by counting a common group of subjects in Alaska.

For the 1989-90 survey, a second detector was added. A $7.5 \mathrm{~cm} \times 7.5 \mathrm{~cm} \mathrm{NaI}(\mathrm{Tl})$ detector was placed close to the chest in addition to a $12.5 \mathrm{~cm} \times 10 \mathrm{~cm}$ detector close to the abdomen and thighs. For a small child, the chest detector was omitted. The counting time for the ${ }^{137} \mathrm{Cs}$ photopeak remained at five minutes. The system was calibrated with three water-filled phantoms (mock-ups of the human body) containing known amounts of ${ }^{137} \mathrm{Cs}$ (Kramer et al., 1991). The phantoms represented an adult, a ten-year-old, and a four-year-old. Corrections were applied for the height and weight of each subject.
Participation was voluntary in the 1989-90 survey of five Arctic communities (Baker Lake, Rae-Edzo, Old Crow, Aklavik, and Fort McPherson). Advertising and word-of-mouth were used to reach as many caribou consumers as possible. As a result, approximately 30 to $40 \%$ of the residents in each community were surveyed. Although selection bias cannot be entirely ruled out, the high participation rate gives assurance that the results are a good representation of community-wide averages.

The same five communities had been surveyed in 196768 , along with a number of other communities. Participation in the earlier survey was somewhat more variable. In many cases, the measurements were carried out in conjunction with community x-ray surveys for tuberculosis, which were done routinely at that time. In all communities, participation was sufficient to allow meaningful comparisons with the 1989-90 survey. Table 1 gives the numbers of participants in each community.

Counting statistics and the application of correction factors gave an overall uncertainty in body burden measurements of $\pm 20 \%$.

\section{Meat Concentrations of ${ }^{137} \mathrm{Cs}$}

This method of estimating caribou consumption is based on the assumption that caribou is the chief source of radiocesium in northern diets. In a report prepared for Health Canada, BEAK Consultants Limited (1995) concluded from measured concentrations of ${ }^{137} \mathrm{Cs}$ in caribou 
meat and reported consumption frequencies that caribou accounted for 87 to $99 \%$ of the ${ }^{137} \mathrm{Cs}$ intake in a traditional Arctic diet. Further evidence will be presented later to support this assumption. It will be shown that not more than $15 \%$ of the radiocesium body burden in northern residents could have come from sources other than caribou.

In the 1989-90 surveys, the concentrations of ${ }^{137} \mathrm{Cs}$ in meat (muscle tissue) were measured by gamma spectroscopy in samples obtained from local hunters at the same time as the body burden measurements were carried out. Past experience has shown that the variances of radiocesium concentrations in samples taken from the same locality at the same time are quite small, and that the mean of a half dozen measured samples would agree to within $10 \%$ with the concentrations people are actually consuming in that community (Marshall and Tracy, 1989).

The problem was more difficult for the 1967-68 whole body survey. Measurements from caribou in Canada were not carried out at that time, but were available from 1964 66 (Marshall and Tracy, 1989). Continuous measurements throughout the 1960s are available for caribou in Alaska (Hanson, 1982). Although there was no fresh input of radiocesium to the atmosphere after atmospheric testing by the major powers ceased in 1962, the overall annual concentrations in caribou did not decrease significantly from 1964 to 1968 . We have conservatively assumed that the radiocesium concentrations in Canadian caribou during 1967-68 were not different from those in 1964-66. At worst, this assumption could overestimate meat concentration, and hence underestimate consumption, by as much as $25 \%$. It would definitely not overestimate consumption. For each community in the 1967-68 survey, the caribou values were taken from the nearest herds or from the herds that particular community was likely to have been hunting.

\section{The Biokinetic Parameters, $f_{1}$ and $T_{1 / 2}$}

The biokinetic parameters, $\mathrm{f}_{1}$ and $\mathrm{T}_{1 / 2}$, are known from the literature (ICRP, 1979; Schwartz and Dunning, 1982) and have been confirmed independently by measurements at this laboratory (Tracy et al., 1993). We have taken the GI absorption factor, $\mathrm{f}_{1}$, to be 1.00 , i.e., the absorption of radiocesium in the gastrointestinal tract is virtually complete. The measurements by Tracy et al. (1993) on fecal excretion of radiocesium indicate that the uptake is greater than 98\%. From Schwartz and Dunning (1982), we have taken the effective half time of radiocesium in the human body to be 96 days for men, 65 days for women, and 33 days in children. The first two numbers compare well with the average measurements of 108 days for three adult male volunteers and 63 days for three adult female volunteers from Tracy et al. (1993).

\section{Diet Survey Questionnaire}

In the 1989-90 survey, each participant was asked to complete a dietary questionnaire at the time that the body
TABLE 2. Caribou consumption frequencies derived from the 1989-90 diet survey questionnaire.

\begin{tabular}{|c|c|c|c|c|c|}
\hline \multirow[b]{2}{*}{ Community } & \multirow[b]{2}{*}{ Gender } & \multirow[b]{2}{*}{ No. of subjects } & \multicolumn{3}{|c|}{ Frequency (times per week) } \\
\hline & & & $\begin{array}{c}\text { Week of } \\
\text { survey }\end{array}$ & $\begin{array}{l}\text { Winter } \\
\text { average }\end{array}$ & $\begin{array}{l}\text { Summer } \\
\text { average }\end{array}$ \\
\hline \multirow[t]{2}{*}{ Baker Lake } & M & 111 & 3.8 & 4.2 & 4.0 \\
\hline & $\mathrm{F}$ & 130 & 3.5 & 3.8 & 4.0 \\
\hline \multirow[t]{2}{*}{ Rae-Edzo } & M & 181 & 3.2 & 3.5 & 3.0 \\
\hline & $\mathrm{F}$ & 155 & 2.6 & 3.1 & 2.9 \\
\hline \multirow[t]{2}{*}{ Old Crow } & M & 40 & 2.6 & 3.9 & 3.1 \\
\hline & $\mathrm{F}$ & 24 & 2.7 & 3.9 & 2.8 \\
\hline \multirow[t]{2}{*}{ Fort McPherson } & M & 42 & 3.9 & 3.5 & 1.9 \\
\hline & $\mathrm{F}$ & 60 & 3.9 & 3.7 & 2.1 \\
\hline \multirow[t]{2}{*}{ Aklavik } & M & 40 & 3.0 & 2.3 & 1.8 \\
\hline & $\mathrm{F}$ & 56 & 3.2 & 2.6 & 1.9 \\
\hline
\end{tabular}

burden measurement was carried out. Interpreters were present to translate questions and record answers from aboriginal languages where appropriate. The questionnaire elicited information on consumption frequencies and amounts of caribou and other traditional foods. The respondents were asked to report caribou consumption in one of five frequency categories: (a) less than once per week, (b) once per week, (c) 2 to 3 times per week, (d) 4 to 6 times per week, or (e) daily or more often. For the purpose of analysis, these categories were assigned numerical frequency values of $0,1,2.5,5$, and 7 times per week, respectively. To elicit information on seasonal differences, we asked respondents to indicate the consumption frequency during (a) the current week, (b) an average week in winter, and (c) an average week in summer. Information was also obtained on consumption of caribou organs other than muscle tissue and on methods of preparing and cooking caribou meat. From a list of other traditional foods, respondents were asked whether the food item was consumed (a) once per year, (b) several times per year, or (c) weekly or more often. The list of traditional foods (Table 3) was compiled on the basis of advice provided by nutritionists from the Health Department, Government of the Northwest Territories. The list may not be exhaustive, but it includes a broad range of traditional foods known to be consumed in the various communities.

\section{RESULTS}

\section{Caribou Consumption Estimates from Body Burden Measurements}

Table 1 summarizes estimated consumption of caribou meat (community averages and 90th percentiles for males and females) derived from the 1967-68 and 1989-90 surveys of ${ }^{137} \mathrm{Cs}$ body burdens and the application of Equation 2. Also displayed are the concentrations of ${ }^{137} \mathrm{Cs}$ 

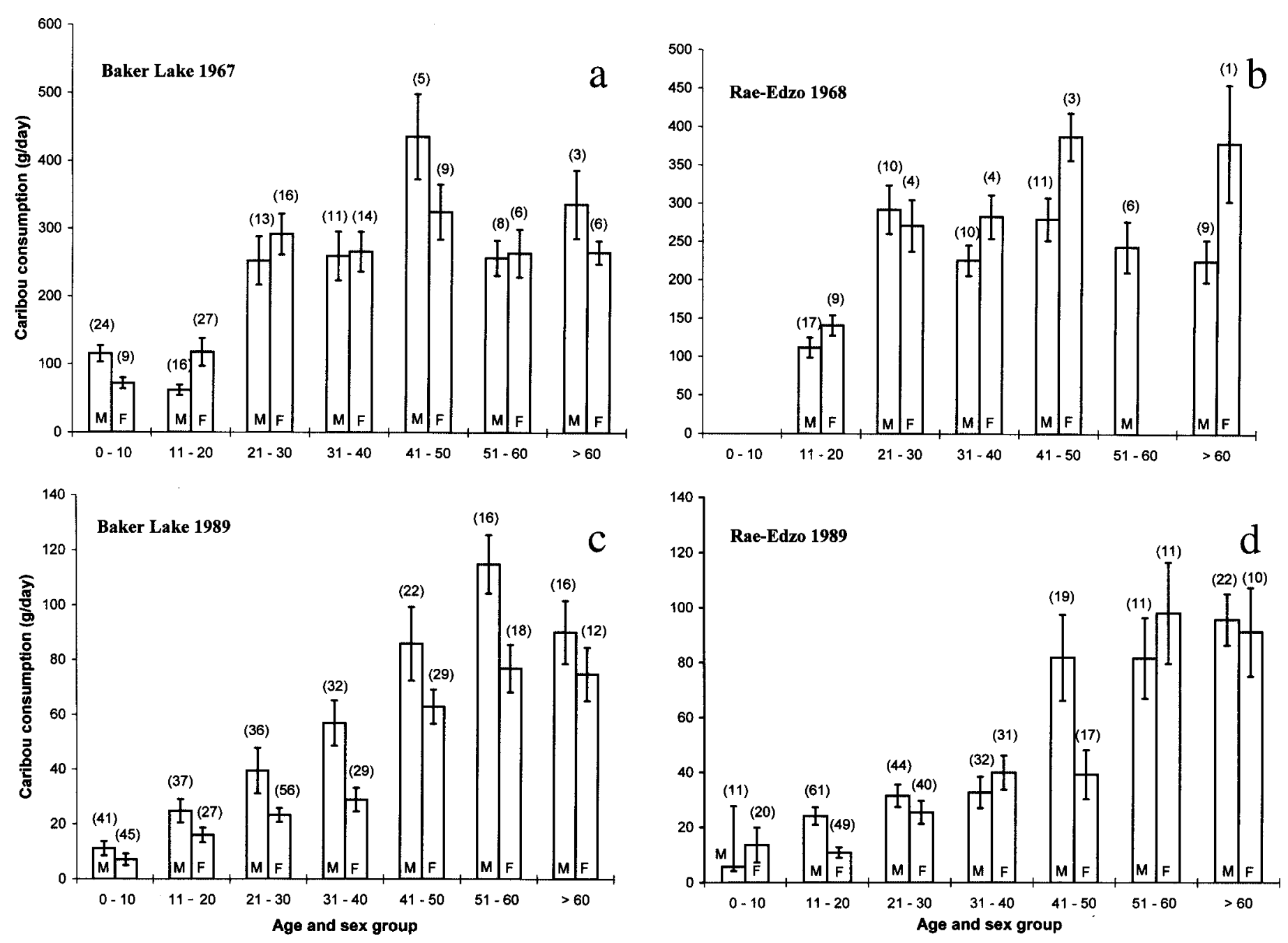

FIG. 1. Caribou consumptions derived from radiocesium body burden measurements as a function of sex and age group in (a) Baker Lake, 1967; (b) Rae-Edzo, 1968; (c) Baker Lake, 1989; (d) Rae-Edzo, 1989. The number of subjects in each age and sex group is given in parentheses above the respective bar. Errors are standard errors of the mean $\left(\sigma_{\mathrm{n}} / \mathrm{n}^{1 / 2}\right)$. Note that the vertical scales are different for the earlier and later surveys.

in caribou meat, the numbers of males and females counted in each community, and the average and 90th percentile body burdens. Note that the average consumption had decreased by a factor of about three (range of two to four) between the 1967-68 and 1989-90 surveys. This decrease indicates a definite shift in caribou consumption during the 20-year period.

Further insight on age and sex variations in consumption patterns for the communities of Baker Lake and RaeEdzo is given in Figure 1a-d. The graphs clearly show that the decrease in caribou consumption was more pronounced for younger adults $(<40)$ than for older adults. This indicates a shift away from caribou consumption by people who had reached adulthood since the late 1960s. The patterns are less clear with regard to variations between males and females. The statistics were somewhat poorer for the 1967-68 survey; however, there were no significant differences between males and females. On the other hand, the 1989 results for adults from Baker Lake and at least the 41 to 50 age group for Rae-Edzo imply higher consumption for men than for women. If this trend proves valid, then caribou consumption had been decreasing more quickly for women than for men in the time between the two surveys.

Table 1 presents caribou consumption estimates for six other communities that showed elevated body burdens during the 1967-68 survey, but were not re-surveyed in 1989-90. The community with the highest body burdens, Rae Lakes, showed average consumption of 200 to $300 \mathrm{~g}$ per day, with 90th percentile consumption of 300 to $400 \mathrm{~g}$ per day. Note that the three Mackenzie Valley communities of Fort Hope, Fort Norman, and Fort Franklin were grouped together. The three communities had shown very similar body burden measurements in the 1967-68 survey (Tracy et al., 1997).

\section{Frequencies of Caribou Consumption Reported from the Diet Survey Questionnaire}

Because of methodological problems in describing the size of meat servings, it was not possible to derive consistent estimates of caribou consumption from the 1989-90 
TABLE 3. Percentage of respondents who reported consuming food items at least once per year.

\begin{tabular}{|c|c|c|c|c|c|c|c|c|c|c|c|c|c|c|c|c|c|c|c|c|}
\hline $\begin{array}{l}\text { Community } \\
\text { Frequency }^{1}\end{array}$ & low & mid & high & total & low & mid & high & total & low & mid & high & total & low & mid & high & total & low & mid & high & total \\
\hline \multicolumn{21}{|l|}{ Mammals: } \\
\hline Caribou & - & 4.7 & 91.8 & 96.5 & - & 6.3 & 90.5 & 96.8 & - & 9.4 & 90.6 & 100.0 & - & 8.3 & 89.6 & 97.9 & - & 4.7 & 91.6 & 96.3 \\
\hline Moose & - & - & - & - & 1.4 & 18.4 & 0.6 & 20.4 & 12.5 & 64.1 & 18.8 & 95.4 & 26.0 & 36.5 & 3.1 & 65.6 & 10.3 & 82.2 & - & 92.5 \\
\hline Rabbit & 2.3 & 3.9 & 0.4 & 6.6 & 15.6 & 55.9 & 7.2 & 78.7 & 12.5 & 53.1 & 15.6 & 81.2 & 4.2 & 64.6 & 12.5 & 81.3 & 7.5 & 76.6 & 2.8 & 86.9 \\
\hline Muskrat & - & - & - & - & 8.1 & 34.6 & 3.5 & 46.2 & 14.1 & 42.2 & 6.3 & 62.6 & 14.6 & 46.9 & 1.0 & 62.5 & 10.3 & 45.8 & - & 56.1 \\
\hline Muskox & 34.0 & 2.7 & 0.4 & 37.1 & 1.7 & 2.9 & 1.2 & 5.8 & 1.6 & 1.6 & - & 3.2 & 3.1 & 4.2 & 1.0 & 8.3 & 0.9 & 1.9 & - & 2.8 \\
\hline \multicolumn{2}{|c|}{ Ground squirrel - } & - & - & - & - & - & - & - & 9.4 & 6.3 & 1.6 & 17.3 & - & - & - & - & - & - & - & - \\
\hline Lynx & - & - & - & - & - & - & - & - & 3.1 & - & - & 3.1 & 2.1 & 3.1 & - & 5.2 & 2.8 & 0.9 & - & 3.7 \\
\hline Fish & 5.8 & 59.9 & 13.9 & 79.6 & 11.2 & 64.6 & 13.8 & 89.6 & 6.3 & 48.4 & 32.8 & 87.5 & 3.1 & 50.0 & 41.7 & 94.8 & 0.9 & 90.7 & 7.5 & 99.1 \\
\hline \multicolumn{21}{|l|}{ Birds: } \\
\hline \multicolumn{21}{|l|}{ Plants: } \\
\hline Berries & 29.7 & 40.9 & 5.4 & 76.0 & 12.7 & 55.3 & 8.7 & 76.7 & 10.9 & 62.5 & 15.6 & 89 & 6.3 & 82.3 & 1.0 & 89 & 0.9 & 89.7 & - & 90.6 \\
\hline Wild rhubarb & - & - & - & - & - & - & - & - & 10.9 & 56.3 & - & 67 & 6.3 & 16.7 & - & 23.0 & 1.9 & 59.8 & - & 61.7 \\
\hline Labrador tea & 0.4 & 0.4 & - & 0.8 & 0.9 & 1.7 & 2.3 & 4.9 & 9.4 & 37.5 & 7.8 & 54.7 & 3.1 & 15.6 & 1.0 & 19.7 & 4.7 & 52.3 & - & 57.0 \\
\hline Wild onions & - & 0.4 & - & 0.4 & - & - & - & - & 4.7 & 25.0 & 3.1 & 32.8 & 1.0 & - & - & 1.0 & 0.9 & 0.9 & - & 1.8 \\
\hline
\end{tabular}

${ }^{1}$ Frequency: low $=$ once per year; mid $=$ several times per year; high $=$ weekly or more often; total $=$ low + mid + high.

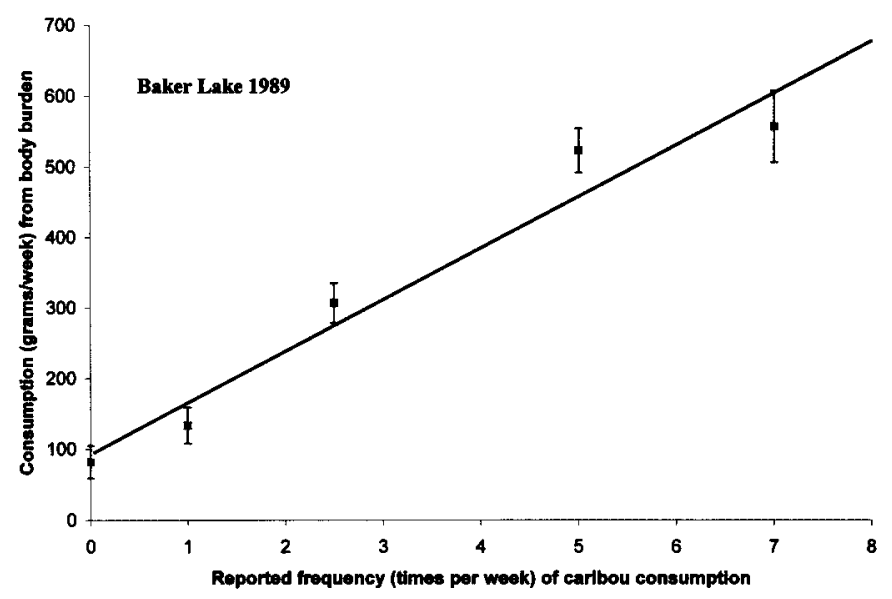

FIG. 2. Weekly caribou consumption derived from body burden measurements versus reported frequency of caribou consumption for Baker Lake, 1989. The frequency categories used are (0) less than once per week; $(1)$ once per week; (2.5) two to three times per week; (5) four to six times per week; (7) daily or more often. The data have been fitted to a regression line $\mathrm{y}=92+74 \mathrm{x}$ (correlation coefficient $=0.977 ; p<0.05)$.

questionnaire responses. However, the responses did provide useful information on the frequency of consumption of caribou and other traditional foods.

Table 2 summarizes the average frequency of caribou consumption reported in each of the five communities surveyed in 1989-90. There appeared to be no significant differences betweeen the frequencies reported by males and those reported by females. For the communities of Baker Lake, Rae-Edzo, and Old Crow, where overall caribou consumption was high, the frequencies appeared

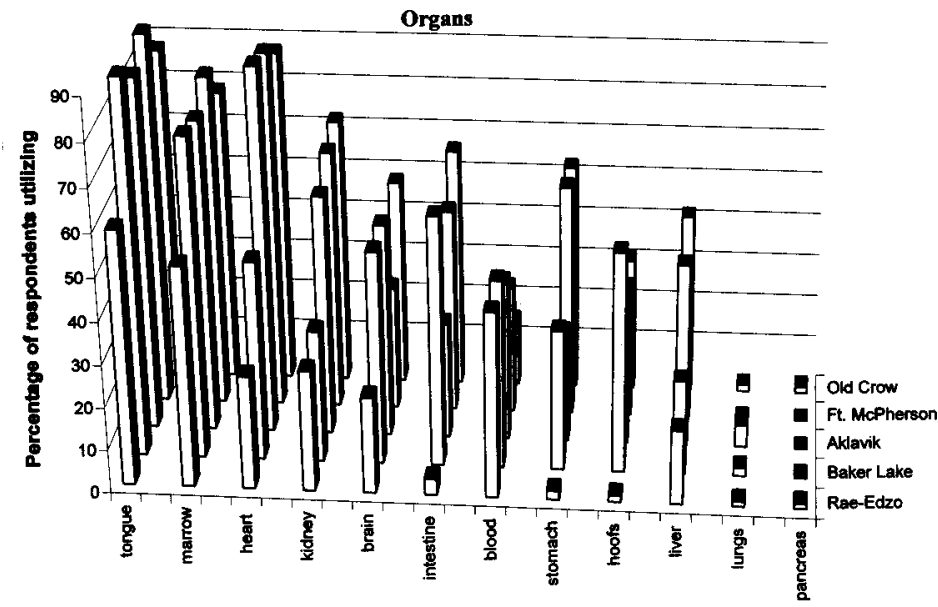

FIG. 3. Percentages of caribou consumers who reported eating various organs and tissues.

relatively consistent from winter to summer, with 3-4 caribou meals per week. For Aklavik and Fort McPherson, where overall consumption was lower, the summer frequencies decreased to about 2 meals per week. Wein and Freeman (1995) reported a caribou consumption frequency for Old Crow of 240 times per year, or 4.6 times per week on a year-round basis. By comparison, our results for this community showed caribou was consumed 3.9 times per week during the winter and 2.8 to 3.1 times per week during the summer.

To demonstrate that these reported frequencies are meaningful, Figure 2 shows the weekly caribou consumption (based on body burden measurement) versus the 


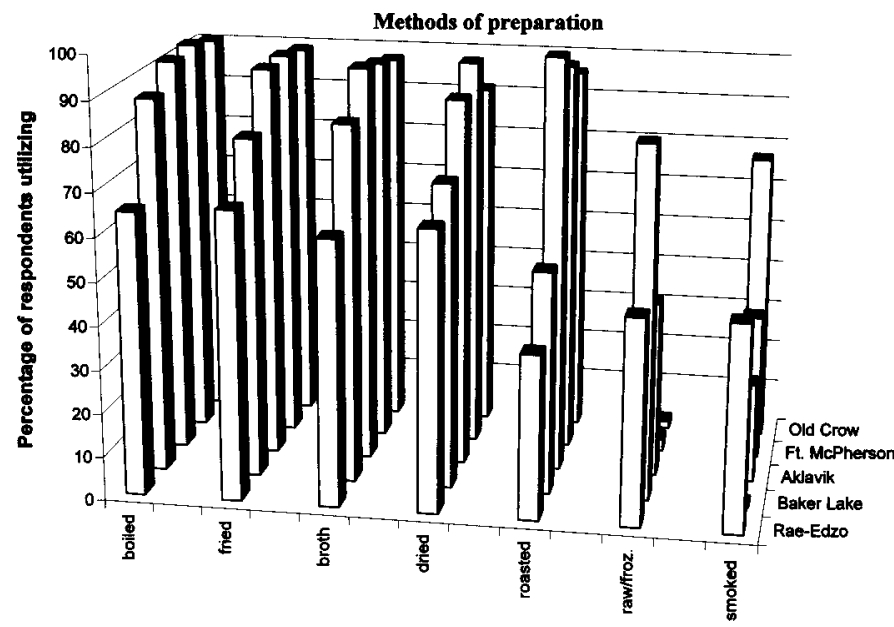

FIG. 4. Percentages of caribou consumers who reported using various methods of meat preparation.

reported consumption frequency for Baker Lake. The data have been fitted to a straight line given by $y=92+74 x$. The non-zero intercept on the y-axis may indicate the contribution of radiocesium from other traditional foods. The estimated consumption based on body burden measurements clearly increases with the reported frequency of consumption (correlation coefficient $=0.977 ; p<0.05$ ). This correlation supports the assumption that caribou meat is the principal contributor to radiocesium body burden, especially among heavy consumers of caribou. In the 1967-68 survey, Bird (1968) also found that measured body burdens correlated well with the three broad categories of "frequent," "occasional," or "rare" consumers of caribou.

\section{Consumption of Other Caribou Organs besides Muscle Tissue}

Figure 3 shows the reported consumption of other caribou organs and tissues for the five communities surveyed in 1989-90, Baker Lake, Rae-Edzo, Old Crow, Aklavik, and Fort McPherson. Each result is the percentage of the total number of caribou meat eaters in a community who reported consuming a particular organ or tissue at least once per year. The organs are arranged roughly in order of decreasing use.

The tongue seemed to be favoured by almost everyone, and the heart was almost as favoured except in Rae-Edzo, where its consumption fell to $25 \%$. It is significant that the bone marrow was eaten by over $50 \%$ of consumers in all communities, and brain, by $25-50 \%$ of caribou eaters. These items provide some degree of fat from an animal that has only very lean muscle tissue. Only about $25 \%$ of consumers reported eating liver and kidney in Baker Lake and Rae-Edzo, but the proportion rose closer to $50 \%$ in the Mackenzie Delta communities. Information on liver and kidney consumption is important, since these organs are known to concentrate ${ }^{210} \mathrm{Po}$ and various trace metals such as cadmium (Indian and Northern Affairs Canada, 1997).
Very little of the caribou is wasted: some communities reported high consumption of intestines and hoofs.

Variations between communities may reflect cultural differences or merely local preferences. It is noteworthy that organ consumption was lower in Rae-Edzo than in the other communities.

\section{Methods of Caribou Meat Preparation}

It is also of interest to note the various methods of meat preparation in the five communities. Figure 4 gives the percentage of people in each community who reported using a given method at least once. The methods are arranged in order of decreasing utilization. The results show a variety of methods and no clear trend with community. Boiling is important in that it may remove a significant amount of a contaminant such as radiocesium. However, a high proportion of people reported consuming the broth, which means they would still ingest the contaminant removed from the meat by boiling.

\section{Consumption of Other Traditional Foods}

Table 3 summarizes information on the use of traditional food items, grouped as terrestrial mammals, freshwater fish, birds, and plants. (Marine mammals and marine fish were not significant items in these five inland communities.) The questionnaire did not distinguish between different species of fish. The values in Table 3 are the percentages of all questionnaire respondents who reported using the food item at least once during the year. In each community, questionnaires were administered to approximately 30 to $40 \%$ of the population and tended to focus on those people who were likely to have consumed traditional foods. In this sense, the percentages should be regarded only as a relative indication of the preferences for various food items. Some frequency information was available from the survey. Respondents were asked to indicate whether they consumed the item once per year (low), several times per year (mid), or weekly or more often (high).

Figure $5(a-c)$ illustrates the percentage utilizations within the groupings of mammals, fish and birds, and plants. Virtually $100 \%$ of the respondents in every community reported eating caribou. In Old Crow and Fort McPherson, over $90 \%$ of respondents reported consuming moose. However, Table 3 shows that most people consumed moose only several times per year, whereas they consumed caribou weekly or more often. Significant consumption of muskox occurred only in Baker Lake, where $37 \%$ reported consuming it (most of them only once per year). Caribou and muskox were the only mammals with significant consumption in Baker Lake. Rabbits and muskrat were popular among the other four communities, where one-half to two-thirds of people reported consumption. Beaver, porcupine, ground squirrel, and lynx were consumed less frequently. 

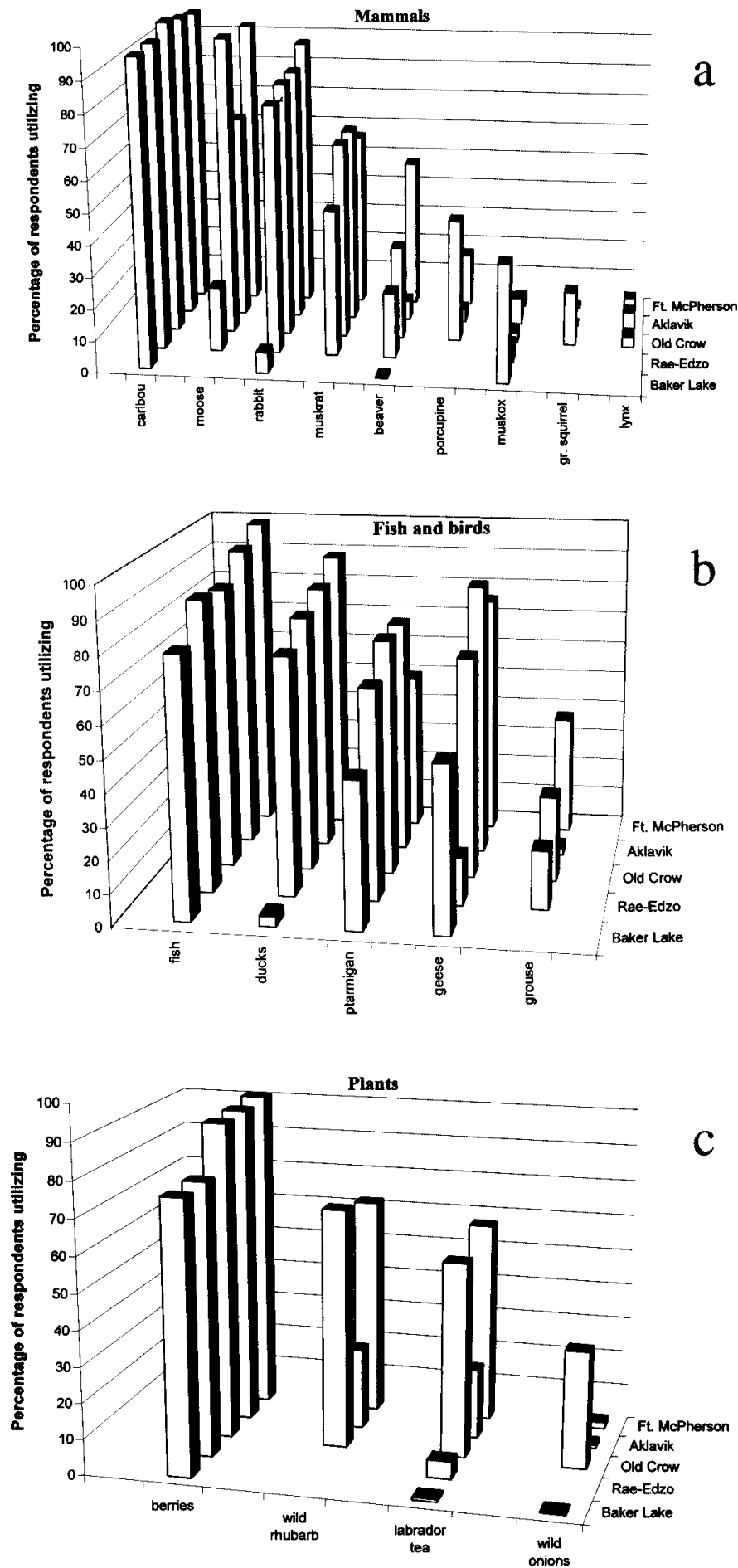

FIG. 5. Percentages of respondents who reported consuming various traditional foods: (a) mammals; (b) fish and birds; (c) plants.

In all communities, $80 \%$ or more of respondents ate fish. Most people reported fish consumption "several times per year," but a significant number stated they ate fish "weekly or more often." For birds, half or more of the respondents in all five communities reported eating ptarmigan. Ducks and geese were most popular in the four Dene communities. Grouse were consumed less frequently. Wild berries were eaten by 75 to $90 \%$ of respondents. Wild rhubarb and Labrador tea were popular in Old Crow, Aklavik, and Fort McPherson.

These results are comparable to those obtained by Wein and Freeman (1995) for Old Crow. They indicated caribou, moose, hare, muskrat, and porcupine as the most frequently consumed mammals and reported infrequent consumption of ground squirrel, black bear, and lynx. Their results showed ducks, geese, ptarmigan, and grouse as the most frequently consumed birds. Wein and Freeman reported (freshwater) fish consumption at 60 times per year. Their respondents ate wild berries 166 times per year.

\section{DISCUSSION}

The caribou consumption estimates obtained by this method are substantially lower than those summarized by Coad (1994) for harvest survey results. For example, Murphy (1986) indicated that $630 \mathrm{~g} \mathrm{~d}^{-1}$ person $^{-1}$ of meat from large mammals (mostly caribou) was available for consumption by Old Crow residents. Dimitrov and Weinstein (1984) obtained a similar value of $500 \mathrm{~g} \mathrm{~d}^{-1}$ person $^{-1}$ for the Ross River Band in central Yukon.

A more recent 24-hour recall survey was carried out by Berti et al. (1998) for the major Denendeh groups, including the Gwich'in people who inhabit the region of Old Crow. They reported mean caribou consumption of $224 \mathrm{~g} \mathrm{~d}^{-1}$ person $^{-1}$ (males) and $178 \mathrm{~g} \mathrm{~d}^{-1}$ person $^{-1}$ (females) for persons over 40 years age and means of $163 \mathrm{~g} \mathrm{~d}^{1}$ person $^{-1}$ (males) and $122 \mathrm{~g} \mathrm{~d}^{-1}$ person $^{-1}$ (females) for people under 40. Corresponding values for Old Crow from our study are 63 and $39 \mathrm{~g} \mathrm{~d}^{-1}$ person ${ }^{-1}$ (for males and females over 40 ) and 33 and $20 \mathrm{~g} \mathrm{~d}^{-1}$ person ${ }^{-1}$ (for males and females under 40). Our results are somewhat lower than those of Berti et al., but both sets of results confirm the same general trend with age, and both indicate a substantial downward revision of the earlier harvest survey results.

From a 24-hour recall survey, Kuhnlein (cited in Coad, 1994) found all-season caribou consumptions for the Dene/ Metis community of Fort Good Hope of $110 \mathrm{~g} \mathrm{~d}^{-1}$ person ${ }^{-1}$ (males) and $86 \mathrm{~g} \mathrm{~d}^{-1}$ person $^{-1}$ (females). Her values for Colville Lake were considerably higher: $550 \mathrm{~g} \mathrm{~d}^{-1}$ person $^{-1}$ (males) and $220 \mathrm{~g} \mathrm{~d}^{-1}$ person ${ }^{-1}$ (females). These communities were not surveyed in our 1989-90 study, but Kuhnlein's consumption values are quite close to our results for the 1967-68 survey (Table 1). This may indicate that consumption had changed little in these communities between the late 1960s and the 1980s.

Daily caribou consumptions of $77 \mathrm{~g} \mathrm{~d}^{-1}$ person-1 (males) and $61 \mathrm{~g} \mathrm{~d}^{-1}$ person ${ }^{-1}$ (females) for the Inuit community of Broughton Island can be inferred from Kuhnlein (cited in Coad, 1994). A recent survey of Quebec Inuit (J.N. Thompson, Foods Directorate, Health Canada, pers. comm. 1994) indicated a year-round caribou consumption of $42 \mathrm{~g} \mathrm{~d}^{-1}$ person $^{-1}$ (both sexes). These results were generally from coastal communities that rely more on marine mammals and fish, and less on caribou, for protein. 
The results obtained from the body burden measurements tend to be somewhat lower than values obtained from recent 24-hour surveys. Possible sources of error are discussed below.

\section{Uncertainties in the Radiocesium Concentrations in Caribou Meat}

The radiocesium concentrations in meat from the 1989 90 survey are based on measurements carried out for the same time and locality as the whole body surveys and are considered to be accurate to within $\pm 10 \%$. The concentrations from the 1967-68 survey, however, could have been overestimated by as much as $25 \%$. This means that the consumptions for this period could have been underestimated by an equal fraction. In this case, the absolute decrease in consumption from 1967-68 to 1989-90 would have been even greater. Furthermore, the error during the 1967-68 survey would have been the same for all sex and age groups within a given community. Thus the shape of variation with sex and age group would not have been affected.

\section{Radiocesium from Dietary Sources other than Caribou}

If dietary sources of radiocesium other than caribou were contributing significantly to the measured body burdens, then the true caribou consumption values would be even lower than the estimated values. This would not explain why the 24-hour recall values are higher. Nonetheless, it is important to derive an upper limit on the amount of radiocesium that could have come from other sources. This can be done, for example, from diet survey information in Table 3 for the community of Rae-Edzo, which had a large enough number of respondents (185 men and 156 women) to show statistical significance, and which reported consumption of a wide variety of traditional foods. It is assumed that the amount of each item consumed by the community is proportional to the "total" column in Table 3. This assumption will almost certainly overestimate the intake of other traditional foods compared to that of caribou, since it ignores the relative frequency of consumption (whether "low", "mid", or "high").

In caribou meat from the herd utilized by Rae-Edzo, radiocesium concentrations were $293 \mathrm{~Bq} \mathrm{~kg}^{-1}$ in $1986-88$ (Marshall and Tracy, 1989) and up to $2000 \mathrm{~Bq} \mathrm{~kg}^{-1}$ in 1962-66 (Thomas et al., 1992). Levels in moose meat during 1963-65 varied from 15 to $230 \mathrm{~Bq} \mathrm{~kg}^{-1}$ (Thomas et al., 1992), a factor of ten or more below that for caribou during the earlier period. The same authors reported averages of $2 \mathrm{~Bq} \mathrm{~kg}^{-1}$ for 1987 and $7 \mathrm{~Bq} \mathrm{~kg}^{-1}$ for seals in 1965 . For freshwater fish, the highest values reported by Elliott et al. (1981) for ${ }^{137} \mathrm{Cs}$ in fish from Great Slave Lake were 0.1 to $20 \mathrm{~Bq} \mathrm{~kg}^{-1}$ for cisco and 5 to $24 \mathrm{~Bq} \mathrm{~kg}^{-1}$ for trout. (See also Lockhart et al., 1992). BEAK Consultants Limited (1995) quoted a geometric mean ${ }^{137} \mathrm{Cs}$ concentration of 1.7 $\mathrm{Bq} \mathrm{kg}^{-1}$ and a maximum of $15 \mathrm{~Bq} \mathrm{~kg}^{-1}$ from recent measurements in edible waterfowl. Other dietary items, such as plants and small mammals, constitute only a small fraction of the total traditional diet.

If the following ${ }^{137} \mathrm{Cs}$ concentrations are assumed: caribou $-293 \mathrm{~Bq} \mathrm{~kg}{ }^{-1}$; moose and other mammals $-15 \mathrm{~Bq} \mathrm{~kg}^{-1}$ (1/20 that of caribou); fish $-24 \mathrm{~Bq} \mathrm{~kg}^{-1}$; birds $-1.7 \mathrm{~Bq} \mathrm{~kg}^{-1}$; plants $-1.7 \mathrm{~Bq} \mathrm{~kg}^{-1}$ (same as for birds), then the resulting estimate of radiocesium intake would be $85 \%$ from caribou and $15 \%$ from all other sources. Thus the omission of other sources would not cause the caribou consumption to be overestimated by more than $15 \%$.

\section{Contribution of Caribou Organs other than Muscle Tissue or Meat}

Equation 2 ignores the contribution of caribou organs other than muscle to dietary ${ }^{137} \mathrm{Cs}$ intake. Radiocesium tends to be more or less uniformly distributed throughout soft tissues, although some organs may contain up to $30 \%$ higher concentrations. However, the mass of muscle tissue in the caribou body far exceeds that of edible organs, so the consumption of other organs is unlikely to have had a strong influence on the amount of radiocesium consumed.

\section{Seasonal Variability in Radiocesium Intake}

Equation 1 results from the integration to infinity of a simple exponential expression with an assumed constant daily consumption. If the consumption were not constant, then the expression would still give a good estimate of the average consumption over a characteristic time $\mathrm{T}_{1 / 2} / \ln (2)$, i.e., over the previous three to four months. It is this average consumption that is relevant in determining chronic exposure to contaminants in the meat. According to Table 2, the respondents did not make a significant distinction between winter and summer consumption of caribou, although the survey was carried out only once during the year (late winter).

The uncertainties from the various factors can be quantified as follows: body burden measurement $-20 \%$; meat concentration $-10 \%$ in $1989-90$ and $25 \%$ in $1967-68$; other radiocesium sources $-15 \%$. If these errors are combined by taking the square root of the sum of their squares, one obtains an overall uncertainty of $27 \%$ in the 1989-90 survey and 35\% in the 1967-68 survey.

\section{CONCLUSIONS}

It has been shown than measurements of radiocesium body burdens can provide accurate and reliable estimates of caribou consumption in northern communities and help to validate consumption estimates obtained from surveys and interviews. The estimates obtained by the body burden method were somewhat lower than those from 24-hour recall surveys. The differences are partially explainable from uncertainties in the radiocesium body burdens, in the 
meat concentrations, and in other sources of intake. In the communities surveyed, average consumption of caribou decreased by a factor of two to four between the 1967-69 survey and the 1989-90 survey. The decrease was more pronounced for younger adults than for older adults and possibly more for women than for men. The diet survey questionnaire provided useful information on the consumption of caribou organs, methods of meat preparation, and the consumption of other traditional foods in five Arctic communities.

\section{ACKNOWLEDGEMENTS}

The 1989-90 survey would not have been possible without the cooperation and assistance of a great many northern residents. We particularly wish to thank David Simailak, Mayor of Baker Lake, Joe Rabesca, Chief of the Rae Dene Band, and all the citizens of the five Arctic communities who participated in this study. We are indebted to our interpreters-Joan Killulark, Anne Qiyuk, Mary Kreelak, Rosa Rabesca, and Madelaine MacKenzie. Words of thanks for their support are due to the staff and students at the Baker Lake School and the Chief Jimmy Bruneau School in Rae-Edzo. Douglas Urquhart of the Porcupine Caribou Management Board provided essential logistic support for the 1990 survey. Many people in the NWT government have assisted us, notably David Kinloch, Judy Fitzpatrick, Susan Fleck, Diane Thompson, Louise Poole, and all the staff at the community health centres where most of the surveys were carried out. We wish to acknowledge the technical assistance of Health Canada personnel: Leo Noel, Egan Cobbold, Barry Hauck, Renato Falcomer, Joanne Lahey, and William Walker. Dorothy Meyerhof, Chief of the Environmental Radiation Hazards Division, provided valuable advice and support.

\section{REFERENCES}

BEAK CONSULTANTS LIMITED. 1995. Review of human exposure to environmental radiation in the Canadian Arctic. Contract to Radiation Protection Bureau 6302D1, Health Canada, Ottawa K1A 1C1, Canada. Contract Reference No. H4078-4C786/-1-SS.

BERTI, P.R., CHAN, H.M., RECEVEUR, O., MACDONALD, C.R., and KUHNLEIN, H.V. 1998. Population exposure to radioactivity from consumption of caribou among the Dene/ Métis of Denendeh (western Northwest Territories, Canada). Journal of Exposure Analysis and Environmental Epidemiology 8(2):145-158.

BIRD, P.M. 1968. Studies of fallout ${ }^{137} \mathrm{Cs}$ in the Canadian North. Archives of Environmental Health 17:631-638.

BLOCK, G. 1982. A review of validations of dietary assessment methods. American Journal of Epidemiology 115(4):492-505.

BURKE, B.S. 1947. The dietary history as a tool in research. Journal of the American Diet Association 23:1041-1046.

COAD, S. 1994. Consumption of fish and wildlife by Canadian Native peoples: A quantitative assessment from the published and unpublished literature. Contract report for Environmental
Health Directorate, Health Canada, Ottawa, Ontario K1A 1C1, Canada.

DIMITROV, P., and WEINSTEIN, M. 1984. So that the future will be ours; Ross River impact report prepared for the Ross River Band. Available from the Indian and Northern Affairs Library, 10 Wellington Street, Hull, Quebec K1A 0H4, Canada.

ELLIOTT, S.E.M., BURNS-FLETT, C., HESSLEIN, R.H., BRUNSKILL, G.J., and LUTZ, A. 1981. Cesium-137, radium226, potassium- 40 and selected stable elements in fish populations from Great Slave Lake (Northwest Territories), Louis Lake (Saskatchewan), Lake Winnipeg (Manitoba) and Experimental Lakes Area (Northwestern Ontario). Canadian Data Report of Fisheries and Aquatic Sciences 293. Winnipeg, Manitoba: Department of Fisheries and Oceans.

HANSON, W.C. 1982. ${ }^{137} \mathrm{Cs}$ concentrations in northern Alaskan Eskimos, 1962-79: Effects of ecological, cultural and political factors. Health Physics 42:433-447.

ICRP (INTERNAL COMMISSION ON RADIOLOGICAL PROTECTION). 1979. Limits for intakes of radionuclides by workers. ICRP Publication 30, Part I. Annals of the ICRP 2:9193.

INDIAN AND NORTHERN AFFAIRS CANADA. 1997. Canadian Arctic Contaminants Assessment Report. Catalogue No. R72260/1997E. ISBN 0-662-25704-9. Available at the Indian and Northern Affairs Library, 10 Wellington Street, Hull, Quebec K1A 0H4, Canada.

KINLOCH, D., KUHNLEIN, H.V., and MUIR, D.C.G. 1992. Inuit foods and diet: A preliminary assessment of benefits and risks. Science of the Total Environment 122:247-278.

KRAMER, G.H., BURNS, L., and NOEL, L. 1991. The BRMD BOMAB phantom family. Health Physics 61:895-902.

KUHNLEIN, H.V., and KINLOCH, D. 1988. PCB's and nutrients in Baffin Island Inuit foods and diets. Arctic Medical Research 47(Suppl. 1):155-158.

LOCKHART, W.L., WAGEMANN, R., TRACY, B.L., SUTHERLAND, D., and THOMAS, D.J. 1992. Presence and implications of chemical contaminants in the freshwaters of the Canadian Arctic. Science of the Total Environment 122:165-243.

MARR, J.W. 1971. Individual dietary surveys: Purposes and methods. World Review of Nutrition and Dietetics 13:105-164.

MARSHALL, H., and TRACY, B.L. 1989. Radiocesium in the caribou of northern Canada. Internal report available from the Radiation Protection Bureau 6302D1, Health Canada, Ottawa K1A 1C1, Canada.

MURPHY, S.C. 1986. Valuing traditional activities in the northern ecosystem: The case of Old Crow, Yukon Territory. M.A. Thesis, Department of Geography, University of British Columbia. Available from the Indian and Northern Affairs Library, 10 Wellington Street, Hull, Quebec K1A 0H4, Canada.

OVERTON, T.R., and LECUYER, D. 1967. The RPD portable whole body counter design, construction and calibration. Report RPD-58 of the Radiation Protection Division, Health and Welfare Canada, Ottawa, Canada. Available from the authors.

SCHWARTZ, G., and DUNNING, D.E. 1982. Imprecision in estimates of dose from ingested ${ }^{137} \mathrm{Cs}$ due to variability in human biological characteristics. Health Physics 43:631-645. 
STATISTICS CANADA. 1995. Profile of Canada's Aboriginal Population. 1991 Census of Canada. Catalogue number 94-325. Ottawa: Industry, Science and Technology Canada.

SZATHMARY, E.J.E., RITENBAUGH, C., and GOODBY, C.M. 1987. Dietary change and plasma glucose levels in an Amerindian population undergoing cultural transition. Social Science and Medicine 24(10):791-804.

THOMAS, D.J., TRACY, B.L., MARSHALL, H., and NORSTROM, R.J. 1992. Arctic terrestrial ecosystem contamination. Science of the Total Environment 122:135-164.

TRACY, B.L., and KRAMER, G.H. 1993. Assessment of health risks from fallout radiocesium in a hunting and food-gathering society. Public Health Reviews 20:75-86.
TRACY, B.L., KRAMER, G.H., LIMSON-ZAMORA, M., and ZIELINSKI, J.M. 1993. Human uptake of radiocesium from caribou meat. Radiation Protection Dosimetry 48:317-323.

TRACY, B.L., KRAMER, G.H., ZIELINSKI, J.M., and JIANG, H. 1997. Radiocesium body burdens in residents of northern Canada from 1963-1990. Health Physics 72(3):431-442.

USHER, P.J., and WENZEL, M.S. 1987. Native harvest surveys and statistics: A critique of their construction and use. Arctic 40(2):145-160.

WEIN, E.E., and FREEMAN, M.M.R. 1995. Frequency of traditional food use by three Yukon First Nations living in four communities. Arctic 48(2):161-171.

WITSCHI, J.C. 1990. Short-term dietary recall and recording methods. In: Willett, W., ed. Nutritional epidemiology. New York: Oxford University Press. 69-91. 